\title{
Behavioural, growth and immune consequences of early weaning in one-week-old Large-White piglets
}

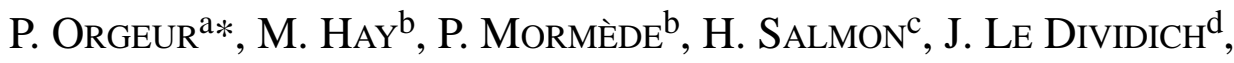 \\ R. NOWAK ${ }^{\mathrm{a}}$, B. SCHAAL ${ }^{\mathrm{a}}$, F. LÉVY ${ }^{\mathrm{a}}$ \\ a Laboratoire de Comportement Animal, PRC UMR 6073 INRA/CNRS/Université, \\ 37380 Nouzilly, France \\ b Neurogénétique et Stress, INSERM U471 INRA, Institut François Magendie, \\ 33077 Bordeaux, France \\ ${ }^{c}$ Pathologie Infectieuse et Immunologie, INRA, 37380 Nouzilly, France \\ ${ }^{\mathrm{d}}$ Station de Recherches Porcines, INRA, 35590 Saint-Gilles, France
}

(Received 12 March 2001; accepted 3 September 2001)

\begin{abstract}
Genetic improvement in sows' prolificity is limited by their milk capacities, which do not allow all piglets to survive or grow normally. This experiment compared the behaviour, growth and immune responses of piglets that were weaned early at 6 days of age (EW) vs. control Large White piglets' (C) suckled by their mothers. Behaviour of 9 litters of 5 to 8 piglets in each group were observed from $\mathrm{d} 5$ to $\mathrm{d} 20$. All piglets were weighed from birth to d74. Three piglets from each group were slaughtered on $\mathrm{d} 36$ for immunological analysis. Until they began to eat dry food, EW piglets walked and vocalised more than $\mathrm{C}$ piglets. After that time, when resting, they were less often lying down and more frequently in contact with littermates under the heater. Aggressive behaviour and bellynosing were more frequent. They displayed a more marked growth check after weaning than did C piglets until 28 days of age. In EW piglets, at 36 days of age, there was a higher density of T- and B-lymphocytes in the gut epithelium and lamina propria, respectively, in relation to the size of lymphoid follicles of Peyer's patches. The results indicate great behavioural adaptation capacities of very early-weaned piglets, together with earlier maturation of their gut immune system.
\end{abstract}

pig / weaning / behaviour / immunology / welfare

Résumé - Conséquences sur le comportement, la croissance et le système immunitaire, d'un sevrage à l'âge d'une semaine, chez des porcelets Large-White. Les capacités laitières limitées des truies hyperprolifiques ne permettent pas à tous les porcelets de survivre ou de croître normalement. L'objectif de cette étude est de mesurer les paramètres comportementaux, zootechniques et immunologiques, exprimés par des porcelets Large-White sevrés ultra-précocement (EW) à 6 jours et des porcelets témoins (C) allaités par leur mère. Les comportements de 9 portées de 5 à 8 porcelets EW

* Correspondence and reprints

E-mail: orgeur@ tours.inra.fr 
et C ont été observés entre J5 et J20. Des pesées ont été effectuées de la naissance à J74. Trois porcelets de chaque groupe ont été sacrifiés à J36 pour des mesures immunitaires. Les porcelets EW se déplacent et vocalisent plus que les $\mathrm{C}$ jusqu'à ce qu'ils commencent à s'alimenter. Ensuite, ils sont moins souvent couchés sur le flanc et plus fréquemment en contact corporel, sous la source de chaleur. Ils sont plus agressifs et se massent et se tètent plus. Ils laissent apparaître un retard de croissance comparativement aux porcelets $\mathrm{C}$, jusqu'à l'âge de 28 jours. Enfin, à l'âge de 36 jours, chez les porcelets $\mathrm{EW}$, la densité en lymphocytes T et B est plus élevée que chez les $\mathrm{C}$, dans l'épithélium et la lamina propria ; résultats en relation avec un plus grand développement des follicules des plaques de Peyer, site où s'initie la réponse immunitaire intestinale. Ces résultats montrent que des porcelets sevrés très précocement sont capables d'une adaptation comportementale rapide et que la maturation de leur système immunitaire digestif est également plus précoce.

porc / sevrage / comportement / immunologie / bien-être

\section{INTRODUCTION}

Hyperprolific sows resulting from SinoEuropean crossbreeding and genetic selection are more and more frequently used in France [9]. At the present time, more than $25 \%$ of these sows produce 15 or more piglets per litter and this number is still increasing. However, the valorisation of these genetic improvements is limited by at least two characteristics. First, neonatal mortality is higher in these hyperprolific sows, because of the increased duration of farrowing with the number of piglets and the decrease of average body-weight at birth. Second, the limited number of functional teats (12 to 14) of hyperprolific sows does not favour optimal survival and growth [7]. Moreover, as individual piglets develop selective teat attachment, competition at suckling which leads to energetic loss and to aggressive behaviour, is likely to be increased within the litters [10].

Breeders to solve these problems use different strategies. One of them consists in weaning supernumerary piglets during the first week postpartum. This procedure is currently used although European legislation prohibits weaning before 3 weeks of age, unless it improves the health and welfare of piglets. Early weaning is also practised to control the spreading of diseases after piglets have gained passive immunity through ingestion of colostrum [1]. This early weaning procedure is associated with sudden changes in social and environmental conditions including the feed regimen. Under practical production this method seems to be efficient which it permits in most of case supernumerary piglets to survive [15]. The psychobiological consequences of such an early weaning remain largely unknown, underlying the originality of this study. There have been already observations that the age at weaning influences subsequent behaviour patterns displayed by the piglets. Weary and Fraser [22] showed that the vocal response of piglets to weaning was stronger in piglets weaned at 3 weeks than in piglets weaned at 4 or 5 weeks. Van Putten and Dammers [21] reported many behavioural differences between piglets weaned at $3^{1 / 2}$ weeks and those kept together with their mother. Worsaae and Schmidt [24] and Dybkjær [5] showed that some behavioural patterns such as belly-nosing or aggressive activity could be modified by several environmental and social changes, including weaning. Worobec et al. [23] reported that piglets weaned at 7 day displayed persistent belly-nosing in contrast to piglets weaned at a later age (d14 and $\mathrm{d} 28$ ). This led them to suggest that piglets do not adapt well to early weaning, and that their welfare may be at risk. However, in these later studies, there was no comparison with piglets suckled by their 
dam at the same age and there was no hormonal or immunological measure of the biological consequences of early weaning.

Therefore the aim of our own study was to characterise the behaviour of piglets during 2 weeks and the weight gain during 66 days after a very early weaning (at 6 days) compared to piglets suckled by their dam. We hypothesised that the behaviour, endocrine function and growth rate would be disturbed by early weaning compared to the situation where piglets remain with their dam until the 28th day of life. Some of these disturbances can modify the expression of normal behaviours of the species [12]. They concern several social activities such as inter individual aggressive behaviour, vocalisations, belly-nosing and resting. Although the neonate piglet is immunocompetent at birth, it is immunologically immature and specially the mucosal immune response [18]. Therefore it could be expected that an earlier contact with microbial flora would enhance the development of the immune system; since the Peyer's patches and lymphocytes from the lamina propria and gut epithelium represent the immune system at the interface between the host and the environment, we have looked at their developments after an early weaning.

Moreover, endocrine modifications following the early weaning have been measured, but the data are presented in another paper [6]. The originality of this experiment was to measure a whole range of consequences of such a very early perturbation of social, environmental and feeding conditions, which could influence the animal welfare.

\section{MATERIALS AND METHODS}

\subsection{Animals and accommodation}

This work was undertaken at the experimental unit of the Laboratory of Reproductive and Behavioural Physiology at Nouzilly, France. Eighteen litters of piglets born from primiparous purebred Large-White sows were studied. The litters were divided into two experimental groups of 9 litters. Piglets of group 1 were weaned at 6 days (Early Weaning: EW). Piglets of group 2 were sow-reared until weaning at 28 days (Control: C). The number of piglets in each litter (Tab. I) was reduced and varied from 5 to 8 (number of piglets was depending on body weight to homogenise each litter. Supernumerary piglets from these experimental litters were adopted by other sows, which have farrow at the same time). The sows were kept in a piggery where the temperature was maintained between 25 and $28^{\circ} \mathrm{C}$. Each sow was restrained in an individual pen of $4,25 \mathrm{~m}^{2}$. Farrowing was induced on the 112 th day of pregnancy with an intramuscular injection of prostaglandin $\mathrm{F} 2 \alpha$ (Alfabédyl ${ }^{\circledR}$ alfaprostol). Each piglet was numbered on its back with permanent ink. Canine teeth clipping and tails docking were carried out on the day of birth and all males were castrated on the 13th day.

\subsection{Weaning procedure}

On the day of weaning (d6 postpartum), EW piglets stayed in their pen or were removed into an identical farrowing pen situated in another room depending on space

Table I. Repartition of piglets within experimental litters.

\begin{tabular}{cccc}
\hline Number of band & Number of litters C & Number of litters EW & Number of piglets/litters \\
\hline 1 & 3 & 3 & 5 \\
2 & 2 & 2 & 7 \\
3 & 2 & 2 & 8 \\
4 & 2 & 2 & 8 \\
\hline
\end{tabular}


availability. Piglets were weaned a few minutes (5 to 10) before the beginning of observations. Inside these pens, there were a carpet placed under a heating device and two feeding and drinking troughs.

Dry food (powdered sow milk replacer: Biggen Premium, Denkavit, France) was offered ad libitum from two days before weaning on. From day 14 on, this food was mixed with and progressively replaced by pellets (Biggen 1, Denkavit, France). The same diet was available to the $\mathrm{C}$ group from day $11 \mathrm{on}$. Water was provided ad libitum. The drinking trough was filled by hand during the first few days until the EW piglets got accustomed to this device.

\subsection{Behavioural measures}

Each litter was observed 4 hours per day (from 9 to 11 a.m. and from 2 to 4 p.m.) on d5 (the day before weaning of EW piglets), d6 (the day of weaning), d7, d8, d12 and d20. These times of observation were chosen because they correspond to period of non-intervention by breeders during diurnal phase. The rooms where the animals were observed were isolated from outside noises; therefore the activity rhythms in the piggery did not disturb the subjects during the observations. The days of observation were chosen after a preliminary study: the day before weaning is the referent point, the three first days after weaning permit to follow the immediate behavioural perturbations and the other two days were divided to the two following. Trained observers sitting still outside the pen collected the data.

Two recording methods were used to collect the behavioural data.

\subsubsection{Scan sampling was run every ten minutes to assess:}

- the percentage of piglets resting (in pronation or on the flank);

- the percentage of piglets standing (still and moving) and exploring their environment (sniffing the floor or the walls);
- the litter cohesion (percentage of resting piglets in direct body contact and forming the biggest group) and the resting place (either on the carpet, under the heating device or in another place).

The activity of each piglet was recorded to determine these percentages.

\subsubsection{Continuous observations to record:} bouts;

- the number of feeding and drinking

- aggressive behaviour (the number of fights between piglets: a fight involves two piglets and is characterised by a succession of reciprocal butts, bites and pursuits);

- belly-nosing (the number of massages, butting and sucking bouts exhibited by a piglet to the litter mates);

- the duration of vocalisations (the time of collective vocalisations was measured by direct observation when at least 3 piglets were vocalising regardless of the type of vocalisation);

- the frequency of sucking.

\subsection{Growth measures}

All of piglets were regularly weighed (d0, 8, 11, 13, 22, 28 and 74).

\subsection{Quantitative immunohistochemistry of the intestinal mucosa}

Organisation of the lymphoid cells in the epithelium and lamina propria, lymphoblasts or plasma cells were determined as described previously $[13,20]$.

Three EW piglets and $3 \mathrm{C}$ piglets were slaughtered on $\mathrm{d} 36$. One sample per piglet of mucosal duodenum, 5-7 cm length, comprising the first duodenal Peyer patch, was embedded in OCT (Tissue-Tek, Miles Laboratories, Elkhart, IN, USA). Samples were frozen in liquid nitrogen at sampling and stored at $-80^{\circ} \mathrm{C}$ until use. Sections of $8 \mu \mathrm{m}$ 
thickness were fixed in acetone, $20 \mathrm{~min}$ at $-20{ }^{\circ} \mathrm{C}$. T cells were identified by anti-CD2 Mab, MSA4, and B cells by anti-Ig light chain, Mab K193 3E1, as described previously [4]. Counting stained cells with a Leitz microscope under $\times 25$ magnification carried out quantification of cells expressing these different markers. Positive cells in the epithelium, upper and cryptic lamina propria of 5 well-oriented villi from each duodenal sample were recorded separately and respective values averaged.

\section{STATISTICAL ANALYSES}

All the statistical analyses were conducted using SYSTAT statistical software (Systat 6.0: Evanston, USA). A test of Kolmogorov-Smirnov was used to verify the normality of our behavioural data. Because these data lacked normality, nonparametric tests were used. Group comparisons were performed using the KruskallWallis test and intra-group comparisons were analysed using Friedman and Wilcoxon tests. The behavioural results were presented as box and whisker plots where $50 \%$ of the values were within the box and the median was marked with a line. The bars represented the 50th percentiles. Piglets' growth rate and mucosal immune response were analysed using Student $t$-test. In this last analysis, the t-test was done on the means \pm sd for each pig, e.g. with three values per group.

\section{RESULTS}

None of the EW piglet died after early weaning.

\subsection{Behavioural data}

\subsubsection{Locomotor activities}

\subsubsection{Standing position}

The mean percentage of standing piglets varied significantly over time only in the
EW, being higher on $\mathrm{d} 8, \mathrm{~d} 12$ and $\mathrm{d} 20$ than on d5 $(P<0.05, P<0.01$ and $P<0.05$, respectively). Between groups, comparison showed that from $\mathrm{d} 8 \mathrm{on}$, the percentage of standing piglets was significantly higher in the EW than in the $\mathrm{C}$ group (for example, on d8: $40 \%$ in the EW vs. $20 \%$ in the C group, $P<0.001)$. Moreover, the day of weaning (d6) and the day after (d7), standing piglets were seen moving significantly more often in the $\mathrm{EW}$ group than in the $\mathrm{C}$ group (for example, on $\mathrm{d} 6: 15 \%$ in the EW vs. $5 \%$ in the $\mathrm{C}$ group, $P<0.01$ ).

\subsubsection{Resting position}

The percentage of piglets in lateral recumbency decreased progressively after $\mathrm{d} 7$ in the EW group, whereas in the $\mathrm{C}$ group, it decreased significantly only on $\mathrm{d} 20$, in comparison to other days ( $P<0.05$; Fig. 1$)$. After weaning, this percentage was significantly lower in the EW than in the $\mathrm{C}$ group, except on d7 (d6, d20: $P<0.05$; d8, d12: $P<0.001)$.

Moreover, the mean percentage of piglets laying in pronation was significantly higher in the EW than in the $\mathrm{C}$ group on $\mathrm{d} 6$ and $\mathrm{d} 7$ (d6: $34 \%$ in the EW vs. $22 \%$ in the $\mathrm{C}$ group, $P<0.05, \mathrm{~d} 7: 30 \%$ in the EW vs. $22 \%$ in the C group, $P<0.05)$.

\subsubsection{Resting place}

In the $\mathrm{EW}$ unlike in the $\mathrm{C}$ group, the mean percentage of piglets lying under the heating lamp increased from d6 on (Fig. 2). This percentage was significantly higher on $\mathrm{d} 6(P<0.05), \mathrm{d} 7, \mathrm{~d} 8$ and $\mathrm{d} 12$ than on $\mathrm{d} 5$ and it remained higher than in the $\mathrm{C}$ group from d6 until d12.

\subsubsection{Litter cohesion}

Litter cohesion varied significantly overtime only in the EW group (Fig. 3). It decreased on d20 compared to d6 and d7 $(P<0.05)$. Between groups comparison revealed that from the day of weaning (d6) to d12, it was significantly higher in the $\mathrm{EW}$ than in the $\mathrm{C}$ group ( 70 to $85 \%$ vs. 


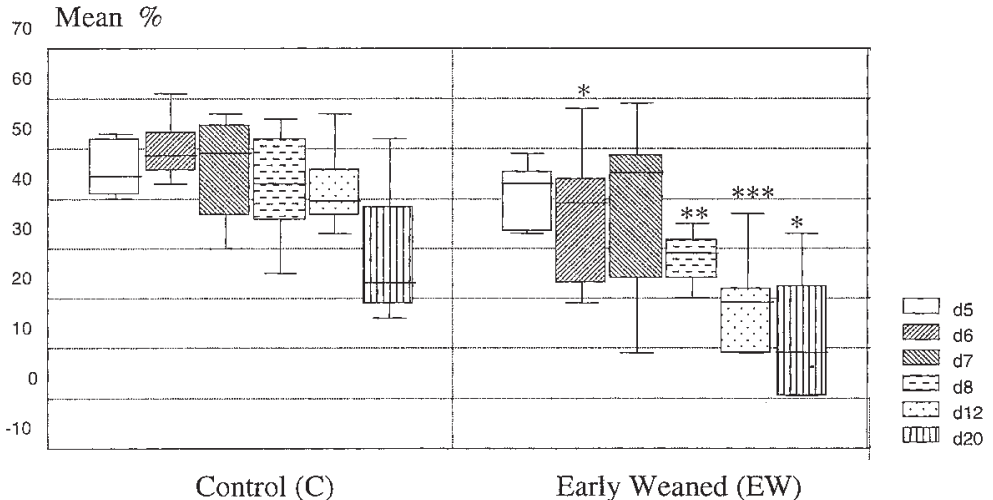

Figure 1. Resting position: median (box: $25 \%, 75 \%$; whisker: min, max) of $\mathrm{EW}$ and C piglets observed laying in lateral recumbency. $* P<0.05, * * P<0.01, * * * P<0.001$. Weaning occurred on d6.

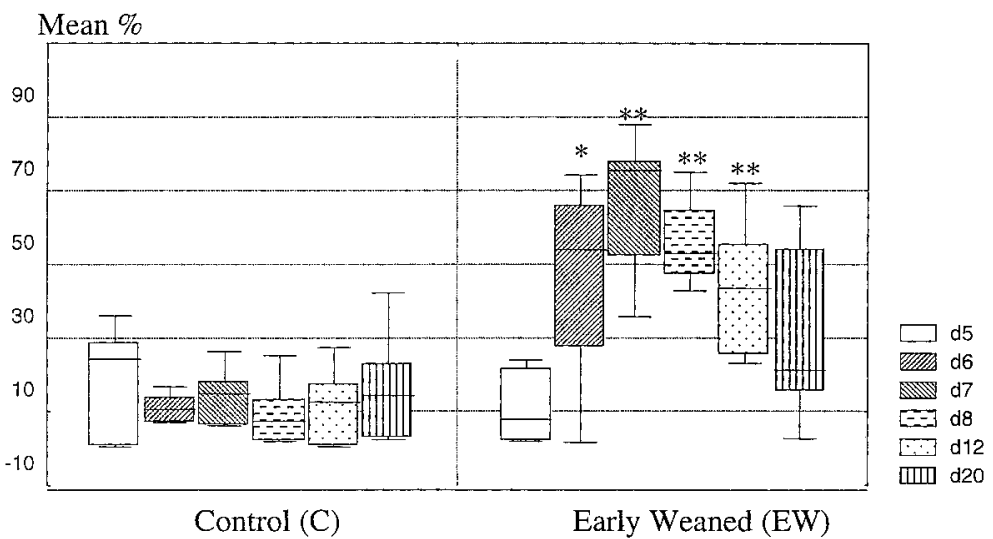

Figure 2. Resting place: median (box: $25 \%, 75 \%$; whisker: min, max) of EW and C piglets observed lying under the heating lamp. $* P<0.05, * * P<0.01$. Weaning occurred on $\mathrm{d} 6$.

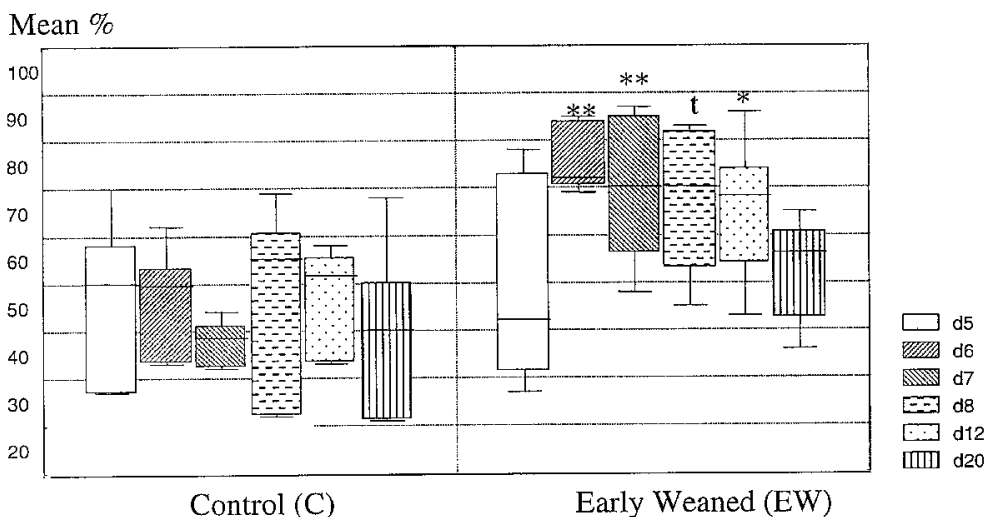

Figure 3. Litter cohesion: median (box: $25 \%$, 75\%; whisker: min, max) of EW and C piglets observed laying in body contact. $P=0.06, * P<0.05, * * P<0.01$. Weaning occurred on d6. 
approximately $55 \% ; P<0.05$ on $\mathrm{d} 8$, $P<0.05$ on $\mathrm{d} 12, P<0.01$ on $\mathrm{d} 6$ and $P<0.001$ on $\mathrm{d} 7)$.

\subsubsection{Exploration}

In the EW group, the mean percentage of piglets sniffing the floor or the walls while standing was significantly higher from $\mathrm{d} 8$ to $\mathrm{d} 20$ than before weaning $(P<0.01$ from $\mathrm{d} 5$ to $\mathrm{d} 8, \mathrm{~d} 12$ and $\mathrm{d} 20$ ), whereas in the $\mathrm{C}$ group this percentage increased only on d20 in comparison to the other days $(P<0.05$ for $\mathrm{d} 5, \mathrm{~d} 7, \mathrm{~d} 12$ and $P<0.01$ for d6 and $\mathrm{d} 8$, respectively). In addition, EW piglets explored significantly more than $\mathrm{C}$ piglets from $\mathrm{d} 8$ to $\mathrm{d} 12$ (between 10 and $20 \%$ in the EW vs. less than $5 \%$ in the $\mathrm{C}$ group, $P<0.05$ on $\mathrm{d} 8, P<0.01$ on $\mathrm{d} 12$, respectively).

\subsubsection{Social interactions}

\subsubsection{Aggressive behaviour}

Aggressive behaviour increased overtime in both groups $(P<0.05$, Fig. 4$)$. In the EW group, the mean number of fights per $4 \mathrm{~h}$ was significantly higher on $\mathrm{d} 8, \mathrm{~d} 12$ and $\mathrm{d} 20$ than the on day before weaning $(P<0.05)$. In the $\mathrm{C}$ group it increased only on $\mathrm{d} 20$ $(P<0.05$ comparatively to $\mathrm{d} 5, \mathrm{~d} 7$ and $\mathrm{d} 8)$. A significant difference was observed between groups, on $\mathrm{d} 7(P<0.05), \mathrm{d} 8(P<0.01)$ and d12 $(P<0.05)$ ( 4 to 7 acts per 4 hours in the EW vs. 1 in the $\mathrm{C}$ group).

\subsubsection{Belly-nosing}

Belly-nosing varied overtime in both groups $(P<0.05$ in $\mathrm{C}$ group, $P<0.001$ in the EW group, Fig. 5). In the EW group,

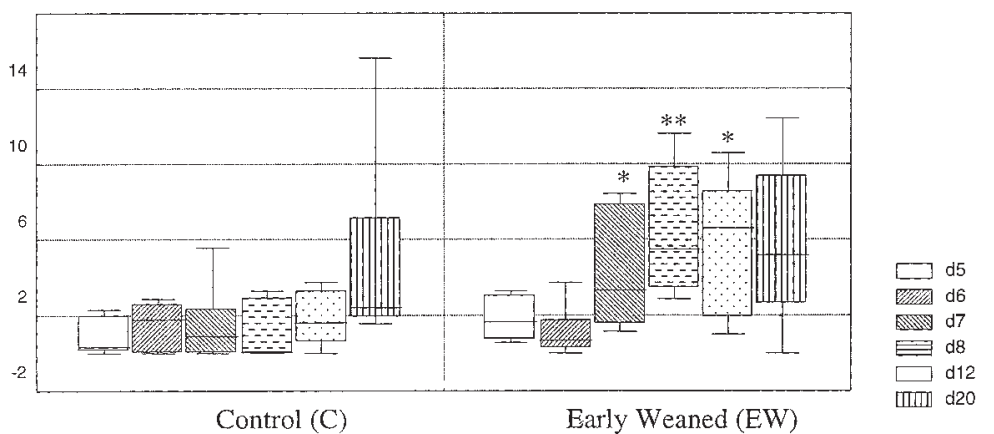

Figure 4. Aggressive behaviour: median (box: 25\%, 75\%; whisker: min, max) of fights observed in $\mathrm{EW}$ and $\mathrm{C}$ piglets per $4 \mathrm{~h}$ of behavioural observation. $* P<0.05, * * P<0.01$. Weaning occurred on $\mathrm{d} 6$.

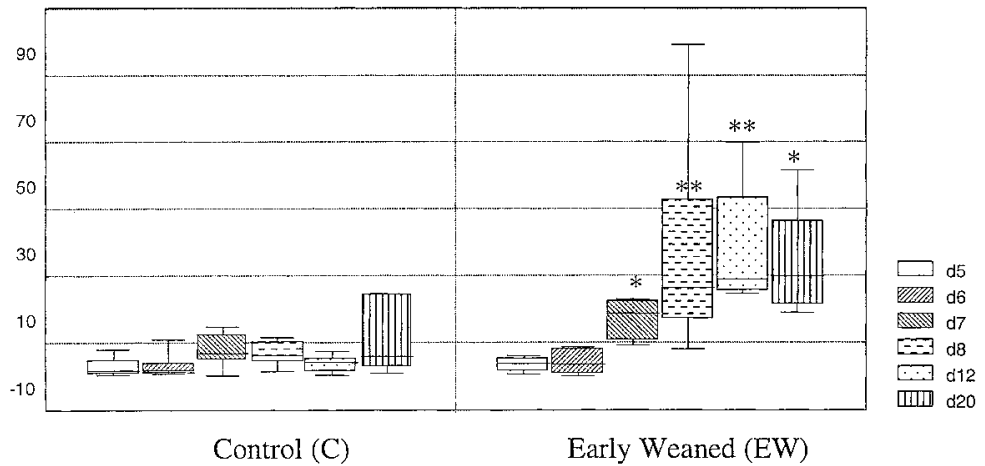

Figure 5. Belly-nosing: median (box: $25 \%, 75 \%$; whisker: min, max) of reciprocal massages, butting and sucking bouts per $4 \mathrm{~h}$ of behavioural observation in EW and C piglets. $* P<0.05, * * P<0.01$. Weaning occurred on d6. 


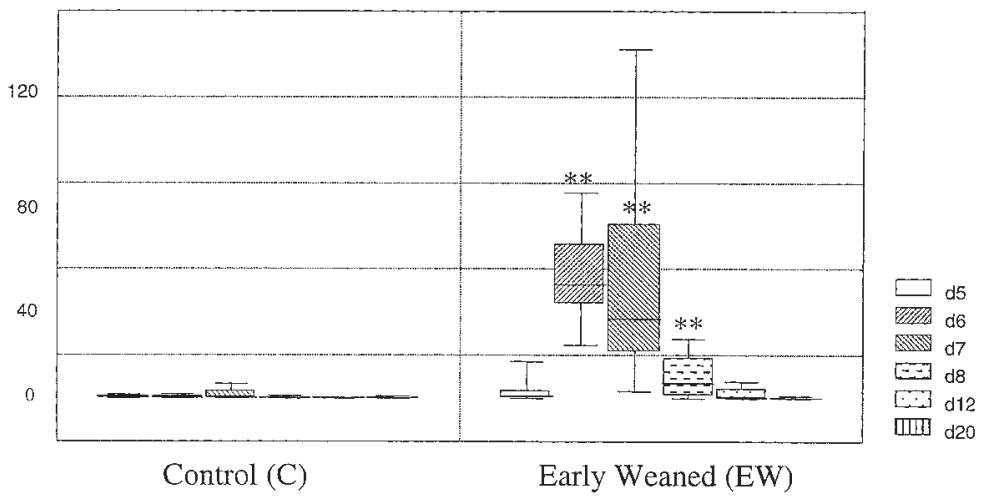

Figure 6. Vocalisations: duration (median, box: $25 \%, 75 \%$; whisker: $\min , \max$ ) of vocalisations per $4 \mathrm{~h}$ of behavioural observation in EW and C piglets. $* * P<0.01$. Weaning occurred on d6.

the mean number of these interactions increased significantly and progressively during the two days after weaning (d6: 5 acts per 4 hours, d7: 17 and d8: 30 ; $P<0.05$ and $P<0.01$, from d6 to $\mathrm{d} 7$ and from $\mathrm{d} 6$ to $\mathrm{d} 8$, respectively) in the EW group, while it remained stable around 5 per 4 hours in the $\mathrm{C}$ group. This activity was significantly higher in the EW than in the C group from $\mathrm{d} 7$ to $\mathrm{d} 20(P<0.05$ on $\mathrm{d} 7$, $P<0.01$ on $\mathrm{d} 8$ and $\mathrm{d} 20, P<0.001$ on $\mathrm{d} 12$, respectively).

\subsubsection{Vocalisations}

$\mathrm{C}$ piglets vocalised very seldom during the experimental period while the EW piglets emitted a lot of distress calls after weaning (Fig. 6). The EW piglets vocalised significantly more for two days after weaning (d6 and d7: $3 \mathrm{~h} 46 \mathrm{~min} \pm 1 \mathrm{~h} 29$ and $3 \mathrm{~h}$ $35 \pm 3$ h 35 per 4 hours, respectively) than before (d5: 13 min \pm 25 min per 4 hours, $P<0.05)$. Their vocal activity then decreased until d20. Vocalisation was significantly higher in the $\mathrm{EW}$ than in the $\mathrm{C}$ group during the 3 days following weaning $(\mathrm{d} 6, P<0.001$, $\mathrm{d} 7$ and $\mathrm{d} 8, P<0.01)$.

Finally, most of modifications of behaviour induced by weaning are transient, however some of them, like belly-nosing, lying position or even aggressive behaviour, persist at the end of the experimentation (d20).

\subsubsection{Feeding behaviour and drinking activity}

The mean number of eating and drinking bouts increased significantly from $\mathrm{d} 7$ to d20 (44 vs. 117 eating bouts per 4 hours) in the EW group $(P<0.05$ between $\mathrm{d} 6$ and $\mathrm{d} 7$ and $P<0.01$ between $\mathrm{d} 6$ and the other days, respectively). By contrast, $\mathrm{C}$ piglets exclusively sucked their dam. Indeed, the number of eating bouts was significantly higher in the $\mathrm{EW}$ than in the $\mathrm{C}$ piglets from d12 to $\mathrm{d} 20(P<0.001)$, while the number of drinking bouts was significantly higher in the EW piglets from $\mathrm{d} 7$ to $\mathrm{d} 20(P<0.01)$.

Logically, after a period of fasting the day of weaning, EW piglets ate and drunk more than $\mathrm{C}$ piglets.

\subsection{Growth rate}

The average body weight of both groups of piglets was similar at birth, averaging $1.36 \mathrm{~kg}$ and $1.47 \mathrm{~kg}$, in EW and C piglets, respectively. From d8 on, EW piglets were lighter than C piglets (d8: 2.29 vs. $2.71 \mathrm{~kg}$, $P<0.02)$. The difference was significant until d28 (6.80 vs. $8.15 \mathrm{~kg}, P<0.05$; Fig. 7) but not on d74. From weaning on, EW piglets grew at a slower rate than $\mathrm{C}$ piglets (97 vs. $250 \mathrm{~g} \cdot \mathrm{d}^{-1}$, from d8 to d13, $P<0.001$; 
Figure 7. Body weight: mean body weight $( \pm$ SD) in early weaned (EW) and control $(\mathrm{C})$ piglets. $* P<0.05$, ** $P<0.01$. Weaning occurred on $\mathrm{d} 6$.

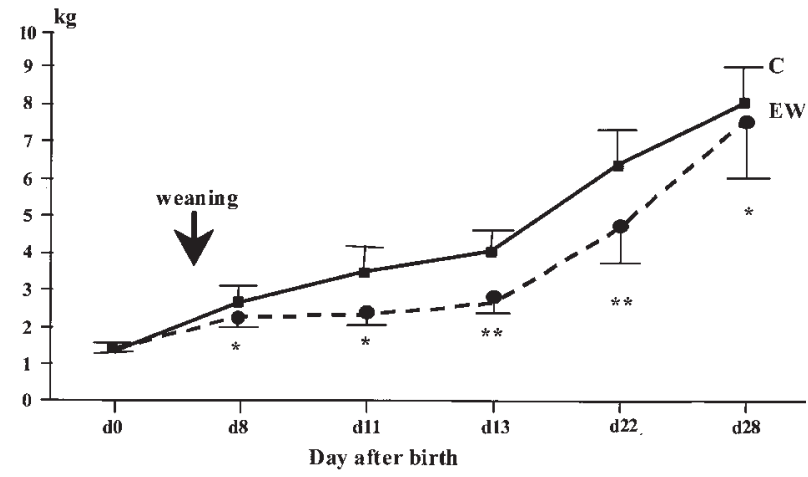

199 vs. $287 \mathrm{~g} \cdot \mathrm{d}^{-1}$ from d13 to d22, $\left.P<0.05\right)$. However, from d22 to d28 the difference was not significant (319 vs. $271 \mathrm{~g} \cdot \mathrm{d}^{-1}$ in $\mathrm{EW}$ and in $\mathrm{C}$ piglets, respectively). On d28 corresponding to the weaning of $\mathrm{C}$ piglets, EW piglets were still $6.6 \%$ lighter than $\mathrm{C}$ piglets. On $\mathrm{d} 74$, average body weight of both groups was similar (36.32 vs. $35.44 \mathrm{~kg}$, in EW and C piglets, respectively) and the mean daily weight gain between d28 to d74 was $642 \mathrm{~g} \cdot \mathrm{d}^{-1}$ vs. $593 \mathrm{~g} \cdot \mathrm{d}^{-1}$ in EW and C piglets respectively.

After weaning EW piglets displayed a marked growth check which is long to compensate.

\subsection{Densities of $\mathbf{T}$ and $B$ cells in the duodenal mucosa}

No significant difference was found between the two groups on $\mathrm{d} 36$ in the villi height (476.1 vs. $456.6 \mu \mathrm{m}$ ) or crypt depth size (110.9 vs. $101.1 \mu \mathrm{m}$, in $\mathrm{C}$ and $\mathrm{EW}$ piglets, respectively). No Ig+ B cells were found in the epithelium. The density of $\mathrm{T}$ cells in the epithelium of the duodenal mucosa was higher in the EW than in the C piglets (6.9 \pm 0.7 vs $5.1 \pm 0.7$ respectively, $P<0.05)$ (Fig. 8).

Labelled Ig light chains were localised in the villus and the crypt of lamina propria

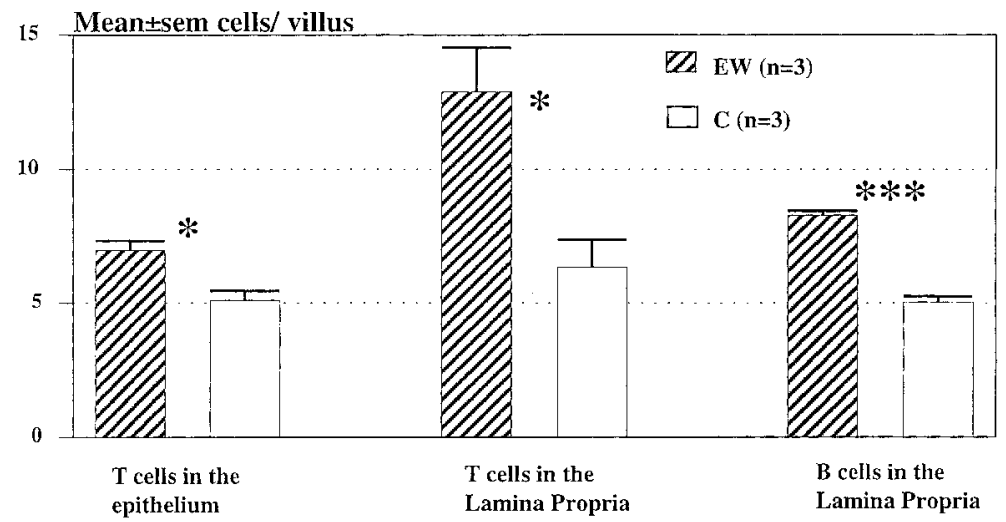

Figure 8. Densities of $\mathrm{T}$ and $\mathrm{B}$ cells in the duodenal mucosa in 36-day-old piglets: mean number $( \pm$ sd) of cells per villus in $3 \mathrm{EW}$ and $3 \mathrm{C}$ piglets. $* P<0.05$, $* * * P<0.001$. Weaning occurred on d6. 
and exhibited the morphology of lymphoblasts, (i.e. a thin rim of Ig+ cytoplasm) or plasma cells. The number of T cells (12.9 \pm 2.8 vs. $6.3 \pm 1.7, P<0.05)$ and $\mathrm{B}$ cells $(8.3 \pm 0.3$ vs. $5.0 \pm 0.3, P<0.001)$ per villus was higher in the lamina propria of the duodenal mucosa of EW than in the $\mathrm{C}$ piglets (Fig. 8), however the T/B ratio was similar in both groups with a predominance of $\mathrm{T}$ cells over the $\mathrm{B}$ cells.

In conclusion, $\mathrm{T}$ and $\mathrm{B}$ cells were higher in duodenal mucosa of EW pigs, both in epithelium and Lamina propria.

The area of B cells follicles of Peyer patches was significantly larger in the EW than in the $\mathrm{C}$ animals $\left(0.4 \pm 0.03 \mathrm{~mm}^{2}\right.$ vs. $0.3 \pm 0.1 \mathrm{~mm}^{2}$, respectively; $P<0.05$ ).

\section{DISCUSSION}

Under our experimental conditions, all of the very early weaning piglets survived.

This study shows that piglets weaned at $6 \mathrm{~d}$ display some behavioural disturbances such as vocalisations, aggressive behaviour, belly-nosing. However part of these changes are transient. Also, early weaning induces changes in the local immune system of the intestine. During the two days following weaning, EW standing piglets walked and vocalised more than $\mathrm{C}$ piglets. This period corresponds to abrupt modifications of social, feeding and even environmental habits, which may be considered as stressful. From the third day after weaning, all EW piglets began to eat regularly dry food and stopped crying. Then, they were seen exploring the pen and staying more often in a quiet standing position at the trough. When they were resting they were more often under the heating device and in litter cohesion and they were less often in lateral recumbency. The aggressive and belly-nosing behaviours were more frequent in this EW than in the $\mathrm{C}$ group. However, most of the perturbations observed during the two first weeks following weaning disappeared on the third week, except the belly-nosing activity and the laying position which persist until the end of the experiment.

According to Mormède [12], the general activity of animals depends on several environmental factors. In our experimental conditions, the change in social environment (absence of mother) and in feeding regimen could explain the increase of vocalisations and the modification of general activity of EW piglets. These behaviours, like resting position - most of piglets were more often on the belly than $\mathrm{C}$ piglets - suggest that EW piglets were more alert during the first period following weaning. This period corresponds to the discovery and the habit of new food and its mode of consumption.

The frequency of exploratory behaviour increased from the day after weaning and remained high during one week, at variance with the data obtained by Worobec et al. [23] who have shown that this activity remained low after an early weaning (7 days). We hypothesise that this increase of exploratory activity can be explained by an active research of the dam and it can facilitate the discovery of food.

Moreover, when piglets were in resting position, they were more often under the heating device and in body contact. This behaviour suggests some impairment in thermoregulation due to the absence of the dam and to the very low food intake [8].

The frequency of belly-nosing of other piglets increased after the beginning of eating. It may compensate the absence of the dam. According to Boe [2] and Worobec et al. [23], the earlier was the weaning, the more frequent was this behaviour. Dybkjaer [5] considered this activity as an indicator of stress. Moreover, this activity confirms the need of contact of these young piglets and indicates the modifications of social relations after an early weaning. Metz and Gonyou [11] report this act as a substitute for teat contact with the sow.

In EW piglets, aggressive behaviour was more frequent than in $\mathrm{C}$ piglets. 
The evolution of these behaviours parallels belly-nosing. As Worobec et al. [23] suggested, the oral activity could stimulate aggressive behaviour. However, no important injury was observed in these animals, likely because these piglets have their canines and tail clipped soon after birth.

Most of the behaviours observed, except the belly-nosing activity and the lying position, did not differ two weeks after early weaning ( $\mathrm{d} 20$ ) between piglets remained with their dam (C) and those, which were early weaned (EW). It may be because some activities increase in $\mathrm{C}$ piglets (e.g. aggressive behaviour) or decrease in EW (e.g. vocalisations, cohesion of litter under the heating device). These results indicate that most of modifications of behaviour induced by weaning are only transient.

On day 74, no difference of body weight was recorded between piglets of these two experimental groups. However, as expected, EW piglets displayed a more marked growth check after weaning than $\mathrm{C}$ piglets. The delay between weaning and the first consumption of dry food ranged from 12 to 48 hours among EW litters. EW piglet's growth rate remained low until $\mathrm{d} 22$. This is related to the fact that food intake $\left(\mathrm{g} \cdot \mathrm{kg}^{-1}\right.$ body weight) in the immediate period following early weaning is also low [14].

Very early weaning implies that piglets are abruptly switched to a complex solid diet. Weaning also is associated with the withdrawal of milk resulting in the loss of milk protective IgA. The specificity of the IgA is directed against food and microbial antigen found in the gut of the sow, the socalled entero-mammary immune link [19]. Absence of Ig+ B cells in the epithelium is in agreement with our previous findings [4, 13].

At 36 days of age, the greater number of $\mathrm{T}$ and $\mathrm{B}$ cells in effector sites (epithelium and lamina propria) of gut immune function indicates a higher recruitment of these cells in EW as compared to the control piglets and this is correlated with the higher increase of Peyer's patches follicle size, a site where the precursors of the gut immune response are initiated. These changes indicate a higher antigenic stimulation in the Peyer's patches and strengthen the ability of the very young piglet to elicit a gut immune response. The increase in B plasma cells has been shown previously to be directly related to the load of microbial antigens [16]. The lower antigenic load in control pigs may result either from masking the antigenic determinants by the maternal $\operatorname{IgA}$ in milk or from non-specific prevention of bacterial colonisation. Whether this increase is directly related to an expansion of the immune repertoire or to non-specific stimulation by bacterial products such as LPS remains to be determined. However, the finding that the bacterial flora is not responsible for the oligoclonality of intra-epithelial lymphocytes [17], but is involved in their clonal expansion, favours the second hypothesis. It is possible that such polyclonal stimulation might enhance specific immune responses against pathogens.

Our results confirm those of Cerneau and Jarrin [3] who described adaptation capacities of piglets weaned very early (5 days). However, as Worobec et al. [23] suggested, the transient behavioural changes observed could indicate that welfare problems induced by very early weaning (7 days) are more obvious than in later weaning conditions (14 or 28 days). Indeed, urinary cortisol levels increased only transiently in earlyweaned piglets, and this change may be related to the acute stress triggered off by the separation from the dam. On the other hand, urinary noradrenaline levels dropped dramatically and remained low to reach control levels at 28 days of age only. This change may be related to the deficit in energy intake [6].

Finally, mother young separation induces important behavioural and growth rate perturbations associated with an elevation of urinary cortisol level [6] which indicate a psychological traumatic. This social stress 
can be considered as transient, even if some of these perturbations persist, while longest behavioural perturbations and decrease of urinary noradrenaline indicate nutritional stress. These results suggest to focalise investigations on quality and appetence of weaning food to limit the energetic deficit observed when piglets are weaned very early.

\section{ACKNOWLEDGEMENTS}

We thank K. Panthou, C. Chevaleyre, E. Chéreau, L. Delattre and G. Venier for their help in data recording and analysis. We are also grateful to E. Venturi and P. Despres for the caring for the animals and respecting the demands of the experimental protocol, and to R.H. Porter for the language corrections. This study was supported by an INRA grant, A.I.P. No. 0693 "BienÊtre Animal et Sciences du Comportement".

\section{REFERENCES}

[1] Aumaître A., Sève B., Nutritional importance of colostrum in the piglet, Ann. Rech. Vét. 9 (1978) 181-192.

[2] Boe K., The effect of age at weaning and postweaning environment on the behaviour of pigs, Acta. Agric. Scand. 43 (1993) 173-180.

[3] Cerneau P., Jarrin D., Comment sevrer à 5 jours d'âge et à $3 \mathrm{~kg}$ de poids vif, Porc Magazine 281 (1995) 35-39.

[4] Dréau D., Lalles J.P., Lejan C., Toullec R. Salmon H., Hypersensitivity to soybean proteins in early weaned piglets: humoral and cellular components, Adv. Exp. Med. Bio. 371 B (1995) 865-869.

[5] Dybkjaer L., The identification of behavioural indicators of "stress" in early weaned piglets, Appl. Anim. Behav. Sci. 35 (1992) 135-147.

[6] Hay M., Orgeur P., Lévy F., Le Dividich J., Concordet D., Nowak R., Schaal B., Mormède P., Neuroendocrine consequences of very early weaning in swine, Physiol. Behav. 72 (2000) 263-269.

[7] Herpin P., Le Dividich J., Conséquences de l'augmentation de la prolificité des truies sur la survie et la croissance du porcelet, INRA Productions Animales 11 (1998) 253-255.

[8] Le Dividich J., Mileu climatique et logement, mise en évidence du rôle primordial du froid dans la mortalité néonatale, in: Le porc et son élevage, Maloine, Paris, 1986, 359-360.
[9] Legault C., Génétique et prolificité chez la truie la voie hyperprolifique et la voie sino-européenne, INRA Productions Animales 11 (1998) 214-218.

[10] Mc Bride G., The "teat order" and communication in young pigs, Anim. Behav. 11 (1963) 53-56.

[11] Metz J.H.M., Gonyou H.W., Effects of age and housing conditions on the behavioural and haemolytic reaction of piglets to weaning, Appl. Anim. Behav. Sci. 27 (1990) 299-303.

[12] Mormède P., Le stress : interaction animalhomme-environnement, Cahiers d'Agriculture 4 (1995) 275-286.

[13] Olivier M., Berthon P., Salmon H., Immunohistochemical localization of the humoral and the cellular components of the immune response in swine gut, Vet. Res. 25 (1994) 57-65.

[14] Orgeur P., Salaün C., Le Roux T., Venturi E., Le Dividich J., L'adoption et le sevrage ultraprécoce: une stratégie pour élever les porcelets en surnombre, J. Rech. Porc. 32 (2000) 143-149.

[15] Anonymous, Conduite d'élevage : sevrage ultraprécoce des surnuméraires, Porc Magazine 314 (1998) 170-171.

[16] Porter P.L., Structural and functionnal characteristics of immunoglobulins of the common domestic species, in: Brandly C.A., Cornelius C.E., Schultz R.D., Adv. Vet. Sc. Comp. Med. Acad. Press. 23 (1979) 1-21.

[17] Regnault A., Levraud J., Lim A., Six A., Moreau C., Cumano A., Kourilsky P., The expansion and selection of $\mathrm{T}$ cell receptor $\alpha \beta$ intestinal intraepithelial T cell clones, Eur. J. Immunol. 26 (1996) 914-921.

[18] Salmon H., The mammary gland and neonate mucosal immunity, Vet. Immunol. Immunopathol. 72 (1999), 143-155.

[19] Salmon H., Mammary gland immunology and neonate protection in pigs, Adv. Exp. Med. Biol., Biology of the mammary gland, Klower Academic Plenum Pub, 480 (2000) 279-286.

[20] Tanneau G., Hibrand-Saint Oyant L., Chevaleyre C., Salmon H., Differential recruitment of $\mathrm{T}$ - and IgA B-lymphocytes in the developing mammary gland in relation to homing receptors and vascular addressins, J. Histochem. Cytochem. 47 (1999) 1581.

[21] Van Putten G., Dammers J., A comparative study of the well-being of piglets reared conventionaly and in cages, Appl. Anim. Ethol. 2 (1976) 239-256.

[22] Weary D.M., Fraser D., Vocal response of piglets to weaning: effect of piglet age, Appl. Anim. Behav. Sci. 54 (1997) 153-160.

[23] Worobec E.K., Duncan I.J.H., Widowski T.M., The effects of weaning at 7,14, 28 days on piglet behaviour, Appl. Anim. Behav. Sci. 62 (1999) 173-182.

[24] Worsaae H., Schmidt M., Plasma cortisol and behaviour in early weaned piglets, Acta. Vet. Scand. 21 (1980) 640-657. 